\title{
Learning Management Systems Comparison
}

\author{
Barbara A. Lewis \\ Lamar University \\ Beaumont, Texas USA
}

blewis lamar@hotmail.com

\author{
Virginia M. MacEntee \\ SUNY Oswego \\ Oswego, New York USA
}

macentee@oswego.edu

\section{Shirley DeLaCruz, Catherine Englander, Thomas Jeffrey, Elizabeth Takach, Sharon Wilson, and Jason Woodall Lamar University, Beaumont, TX, USA}

sxc2580@hal.lamar.edu cce3999@hal.lamar.edu

ilw5961@hal.lamar.edu

\begin{abstract}
The trend toward conversion from traditional classroom to online courses follows the shift of learning theories from the behaviorist orientation that portrays learning as a primarily passive activity to theorist orientation which emphasize the active, reflective and social nature of learning. Learners are increasingly considered to be active constructors rather than passive recipients of knowledge. As this trend increases, questions have surfaced regarding the choice of a learning management system (LMS) to use in developing an online course. The selection of an LMS is critical to student success. That selection needs to be based on both the objectives of the online course and the students' needs. The LMS must have components that will allow the instructor to create a course that emphasizes active learning experiences. This paper will compare nine learning management systems and highlight the product features which enhance their ability to accommodate active learning.
\end{abstract}

Keywords: Learning management systems, LMS, online courseware

\section{Introduction}

This paper will evaluate nine learning management systems (LMS). Each LMS program is based on the ability to accommodate different active learning experiences in online courses. The LMS programs are WebCT, v.4.1; BlackBoard, v. 6.1; Jones E-education; Educator; Angel; .LRN; McGraw Hill Pageout; Moodle; and e-College AU. The comparison will reflect faculty and stu-

\footnotetext{
Material published as part of these proceedings, either on-line or in print, is copyrighted by Informing Science. Permission to make digital or paper copy of part or all of these works for personal or classroom use is granted without fee provided that the copies are not made or distributed for profit or commercial advantage AND that copies 1) bear this notice in full and 2) give the full citation on the first page. It is permissible to abstract these works so long as credit is given. To copy in all other cases or to republish or to post on a server or to redistribute to lists requires specific permission from the publisher at Publisher@InformingScience.org
}

dent perspectives; infrequent references will be made to software administration.

A learning management system must address the needs of the ultimate end user: the learner. Each LMS has key features that allow students to be actively involved in their courses. The 
different learning management systems' key features extend teaching and learning and engage learners in a deeper learning experience.

In choosing and using any type of courseware, an instructor needs to have components that will allow them to create active learning courses. Learning is not a passive activity. Students actively participate in traditional classes by listening and talking to other students and the instructor. In an online classroom, an instructor needs to create an environment which has the students actively participating in lessons and discussions. Through the use of discussions, students are able to share past experience and apply those experiences to their own lives. It is this connection to other students and the instructor that allows the students to feel that they are part of the course.

\section{Discussion}

LMS makes usability the number one concern for instructors as well as students. According to ISO 9241 Part 11 Guidance, usability is "the extent to which a product can be used by specific users to achieve specified goals with effectiveness, efficiency and satisfaction in a specified context of use" (Berns, 2004, p.21). Usability is the key in an online course. The effectiveness of the course will help the learners achieve the specific goals of the course. The ease of navigation through the course will help the learners achieve their goals. If the course is not effective or efficient, then it will affect the students' learning.

Students who take on-line courses tend to be self-directed learners. They show initiative, independence, and persistence in learning. As they accept responsibility for their learning, they see problems as challenges rather than obstacles. They share a high degree of curiosity, a strong desire to learn, and the capacity for self-discipline. They can set goals, make plans, organize their time, and set an appropriate pace for learning. LMS also allow students to do coursework anywhere and anytime. It does not stop a student from participating in a course when they are away from home.

Each component of LMS is important in a student's learning experience. The right components can make a course and the wrong component can destroy a course. Each LMS is compared below by components of the system.

\section{Content Development}

Content development is important in the design of a course. Key throughout the content development is the effectiveness and efficiency of the LMS. The course should be student centered. The student centered approach supports learners and motivates them to learn.

What to put in a course or how to upload content is crucial. Instructors need to be able to upload more than just lecture notes in an online course. They need to be able upload and edit content on line. They also need to create content based on the learners' ability to process and understand the course content. Content development should be coherent and logically sequenced in a way that learners can easily follow the course.

Therefore, an instructor should choose an LMS that supports a student centered approach. It should allow the instructor to design high quality material. The LMS should include support mechanisms that are available online for the learners (Figure 1). 


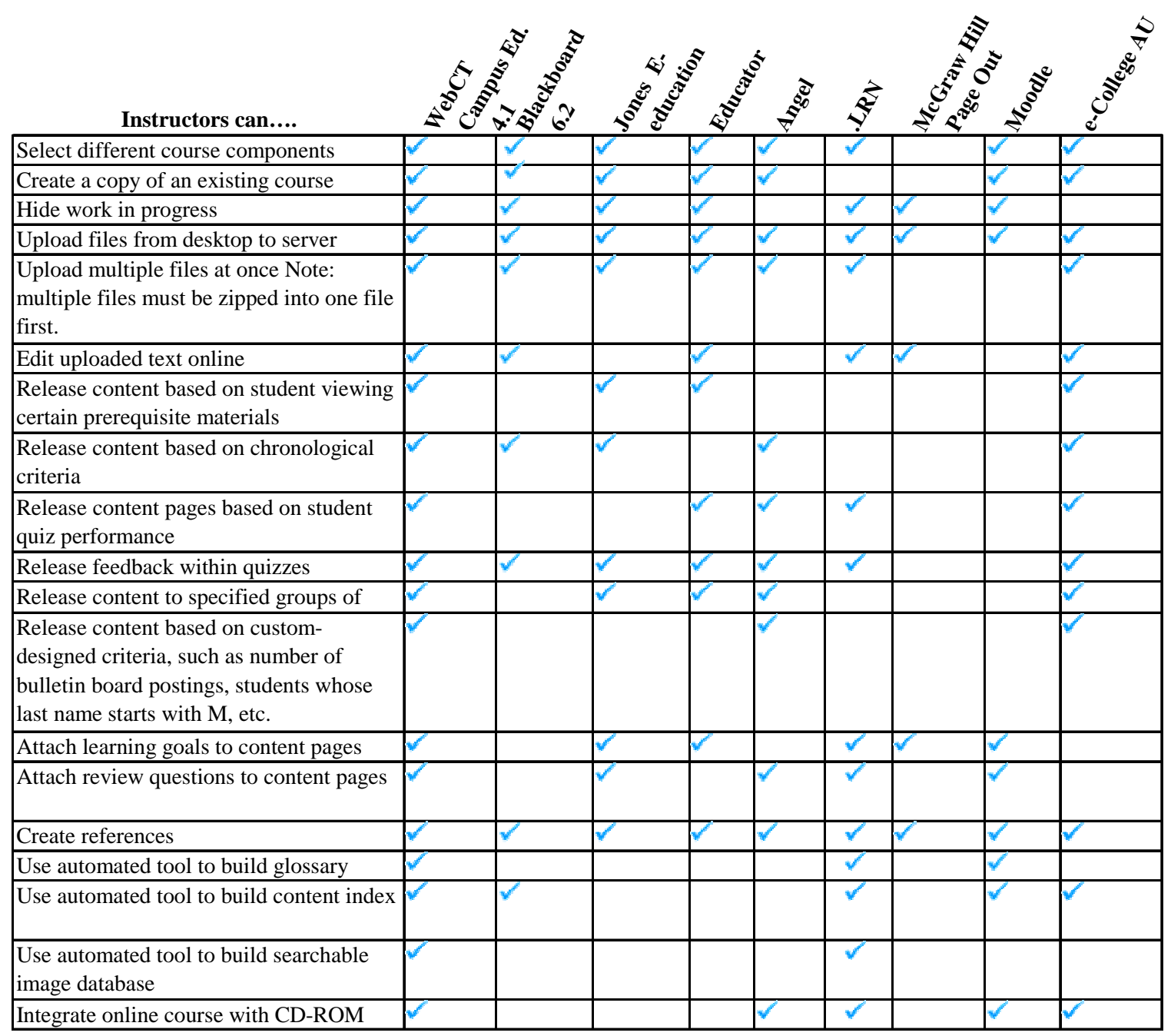

(Adapted from: Lewis, MacEntee, \& Youngs-Maher, 2002)

Figure 1: Content Development

\section{Bulletin Boards/Discussion Area}

Online course with just lecture notes or slide presentations do not allow users to be active participates in the course. Discussion brings a dynamic element to the online class. It is the key to making the course an interactive experience. Discussions allow students to communicate with each other and with the instructor. The discussions allow students to have an active part in building their learning experience. The LMS have different features and the instructor needs to decide which ones are important for the success of the students (Figure 2). 


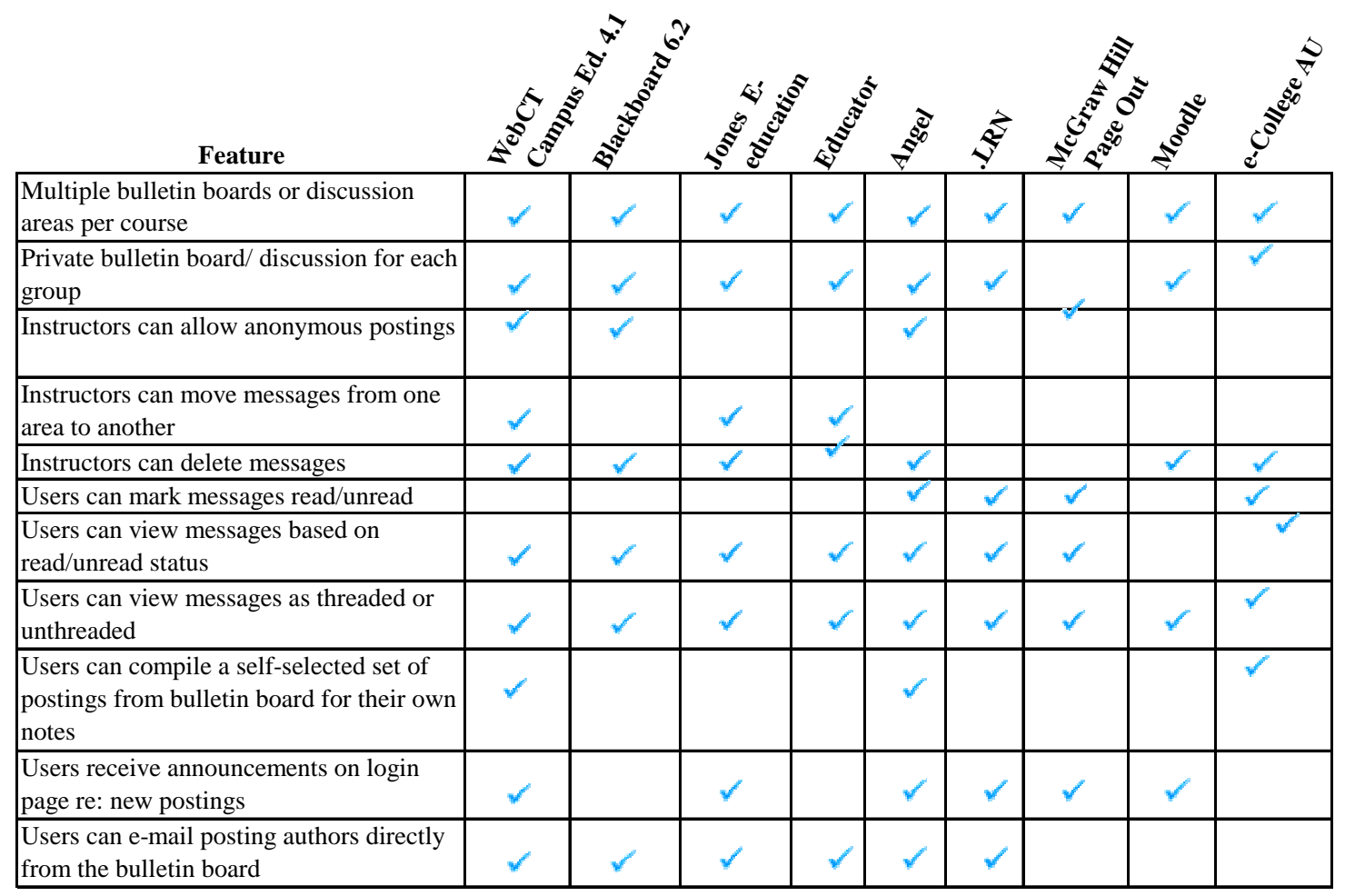

(Adapted from: Lewis, MacEntee, \& Youngs-Maher, 2002)

Figure 2: Bulletin Board/Discussion Area

\section{Group Participation}

LMS allow students to work together in small or large groups. They are able to share documents, chat, send emails and work together in synchronous and asynchronous environments. This is a major advantage to a system (Figure 3). Students do not need to meet in person to work together. They can do everything online. Students like this feature because many times students are not in the same city, state or even country with each other.

\begin{tabular}{|l|l|l|l|l|l|l|l|l|l|}
\hline \multicolumn{1}{|c|}{ Feature } & & & & & \\
\hline $\begin{array}{l}\text { Instructors can have program create } \\
\text { groups and assign members randomly }\end{array}$ & & & & & $\checkmark$ & & & & \\
\hline Users can e-mail members of a group & $\checkmark$ & $\checkmark$ & $\checkmark$ & $\checkmark$ & $\checkmark$ & $\checkmark$ & $\checkmark$ & $\checkmark$ & \\
\hline $\begin{array}{l}\text { Group members can share files } \\
\text { area members can have a private chat }\end{array}$ & & $\checkmark$ & & & $\checkmark$ & $\checkmark$ & & $\checkmark$ & $\checkmark$ \\
\hline $\begin{array}{l}\text { Group members can have private bulletin } \\
\text { boards }\end{array}$ & $\checkmark$ & $\checkmark$ & $\checkmark$ & $\checkmark$ & $\checkmark$ & $\checkmark$ & & & $\checkmark$ \\
\hline $\begin{array}{l}\text { Group members can have Web content } \\
\text { presentation areas }\end{array}$ & $\checkmark$ & & $\checkmark$ & & & $\checkmark$ & & & $\checkmark$ \\
\hline
\end{tabular}

(Adapted from: Lewis, MacEntee, \& Youngs-Maher, 2002)

Figure 3: Group Participation 


\section{Calendar}

A calendar is another key element in a course (Figure 4). How many times have students asked when are assignments due? When are the exams? Instructors can post all due dates on the calendar. Therefore, when a student asks about assignment due dates, the instructor can email the student and tell them it is posted on the calendar. The calendar can also serve as an advance organizer.

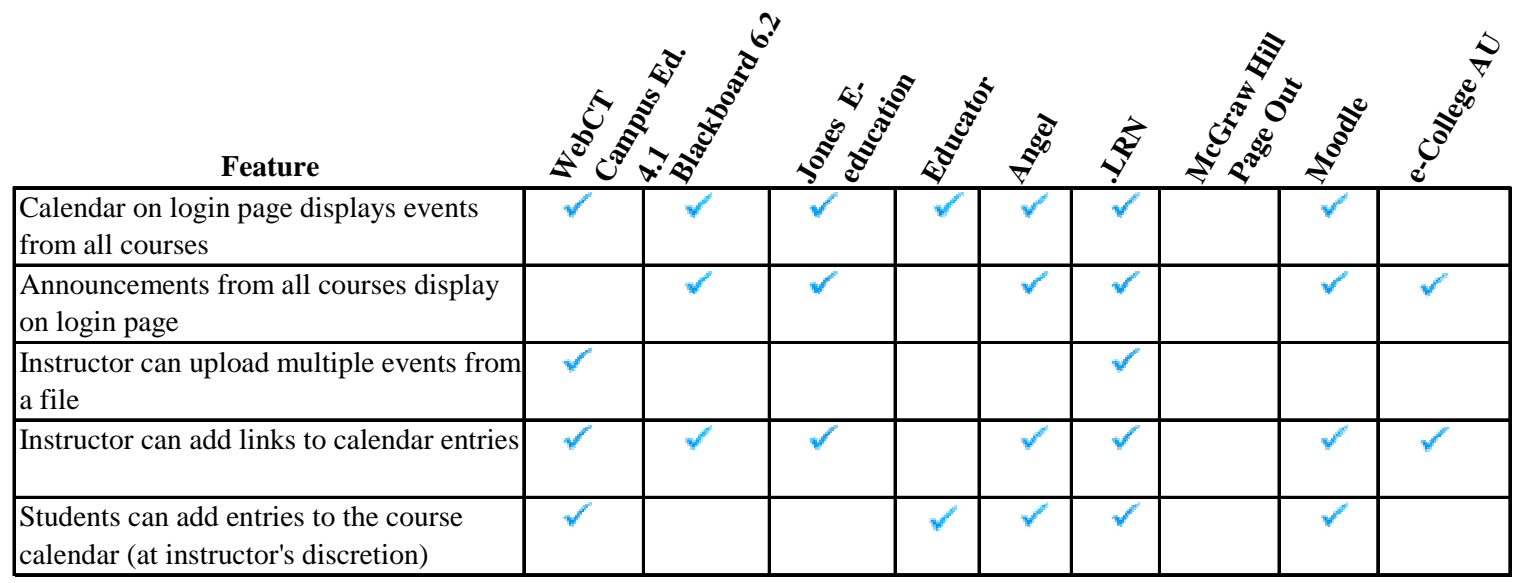

(Adapted from: Lewis, MacEntee, \& Youngs-Maher, 2002)

Figure 4: Calendar

\section{Chat/Whiteboard/E-mail}

Interactivity in an online course is key. Discussion areas are not the only means of interaction between students and students and students and instructor. An instructor can also incorporate synchronous learning through chat rooms and whiteboards (Figure 5). A high school history course instructor can have student engage in an online chat discussion about the civil war. The instructor can have different students answer questions and even post questions to the chat room. The instructor can use the whiteboard to conduct a review session for an exam.

Email is a key component to an online course (Figure 5). It is a means of making a connection to the students. The instructor can use email as a quick method of contacting students or sending notes to those who need more clarification. Students can also use email to connect to the instructor or other students in the course. Email is a good means for groups to communicate with each other. 


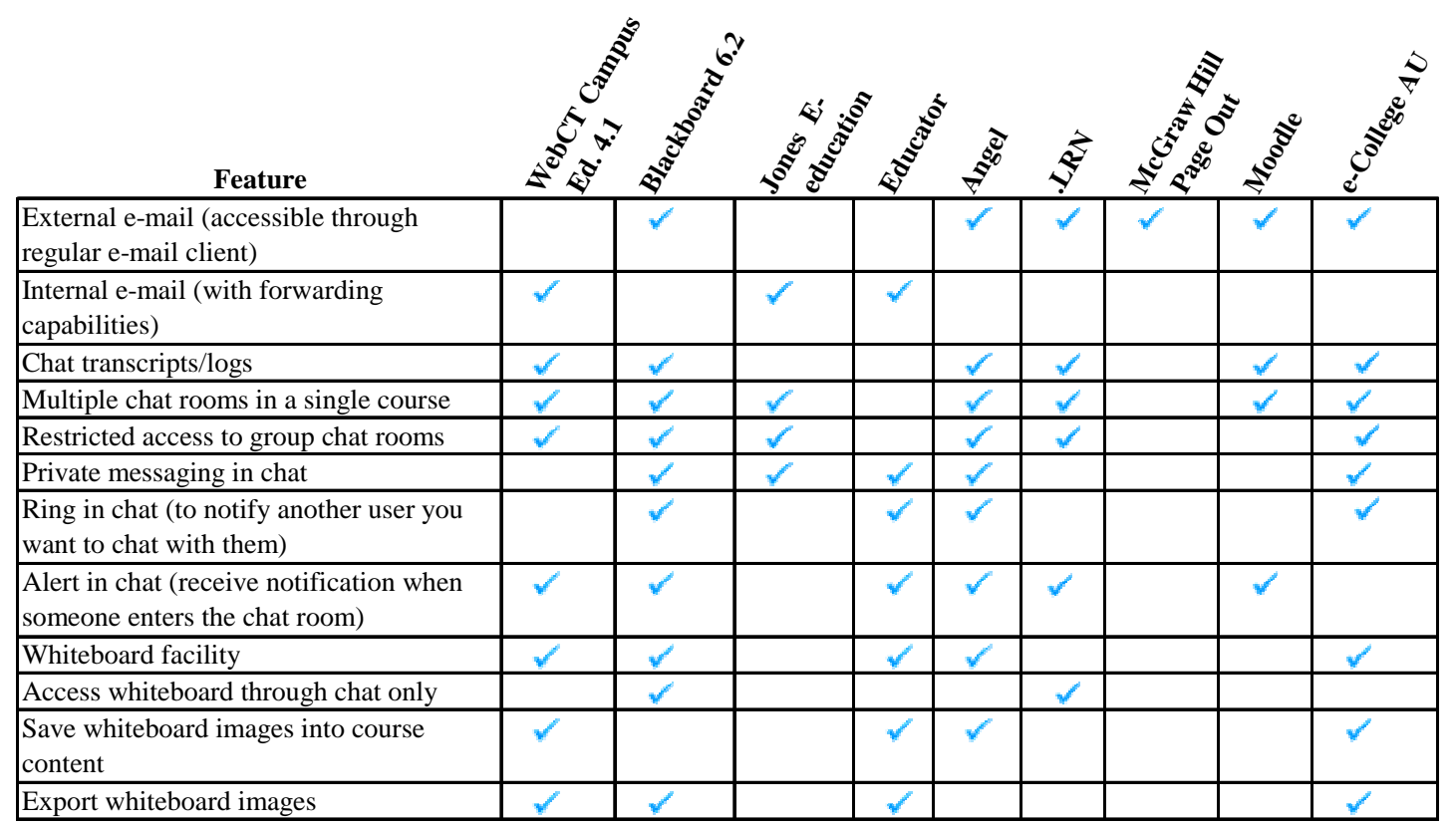

(Adapted from: Lewis, MacEntee, \& Youngs-Maher, 2002)

Figure 5: Chat/Whiteboard/E-mail

\section{Student Study Tools}

Student study tools are important for students (Figure 6). Having study guides available can help students review course materials. Many times when a student is reading lecture notes and study guides, they tend to take notes. Having an online note area for students to attach their own notes to the content is very useful. When a student reviews for a test, they can also view their personal online notes at the same time. Also, if a teacher creates self test for students, they can use the test as a study guide for the course.

One major feature that students appreciate in an LMS is a system so that they can search for particular content (Figure 6). For example, if a student is learning about quadratic equations, they can search the course content to find all pages that deal with quadratic equations.

\begin{tabular}{|c|c|c|c|c|c|c|c|c|c|}
\hline Create study guide & $\checkmark$ & & $\checkmark$ & & $\checkmark$ & $\checkmark$ & $\checkmark$ & & \\
\hline $\begin{array}{l}\text { Resume reading content at previous } \\
\text { stopping point }\end{array}$ & $\checkmark$ & & & & $\checkmark$ & & & & \\
\hline Add notes on course content Web page & $\checkmark$ & & & & $\checkmark$ & $\checkmark$ & $\checkmark$ & & $\checkmark$ \\
\hline Take notes in an internal notepad & $\checkmark$ & $\checkmark$ & & $\checkmark$ & $\checkmark$ & & $\checkmark$ & & $\checkmark$ \\
\hline Compile a set of e-mail messages & $\checkmark$ & & $\checkmark$ & $\checkmark$ & & & & & \\
\hline Compile a set of bulletin-board postings & $\checkmark$ & $\checkmark$ & $\checkmark$ & $\checkmark$ & $\checkmark$ & & & & $\checkmark$ \\
\hline Take self-tests created by the instructor & $\checkmark$ & & $\checkmark$ & $\checkmark$ & $\checkmark$ & $\checkmark$ & $\checkmark$ & $\checkmark$ & $\checkmark$ \\
\hline Search course material & $\checkmark$ & & $\checkmark$ & & $\checkmark$ & & & $\checkmark$ & $\checkmark$ \\
\hline Create original content on own Web pages & $\checkmark$ & $\checkmark$ & 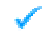 & & $\checkmark$ & & & & $\checkmark$ \\
\hline
\end{tabular}

(Adapted from: Lewis, MacEntee, \& Youngs-Maher, 2002)

Figure 6: Student Tools 


\section{Audio/Video}

Plain text in an online course can get very boring. Often students skim over lecture notes and do not pay attention to detail. Adding audio and video into a course can minimize the skimming of the materials. Instructors can use audio attached to their presentation for students to identify with a voice to the material. They can also use videos of lectures. The videos allow student not only to hear the materially verbally but also to visually see it. It enhances their learning experience (Figure 7). For example, if one is learning sign language, an instructor can videotape a person signing different words and sentences. This video can be edited into smaller parts and attached to several different lectures.

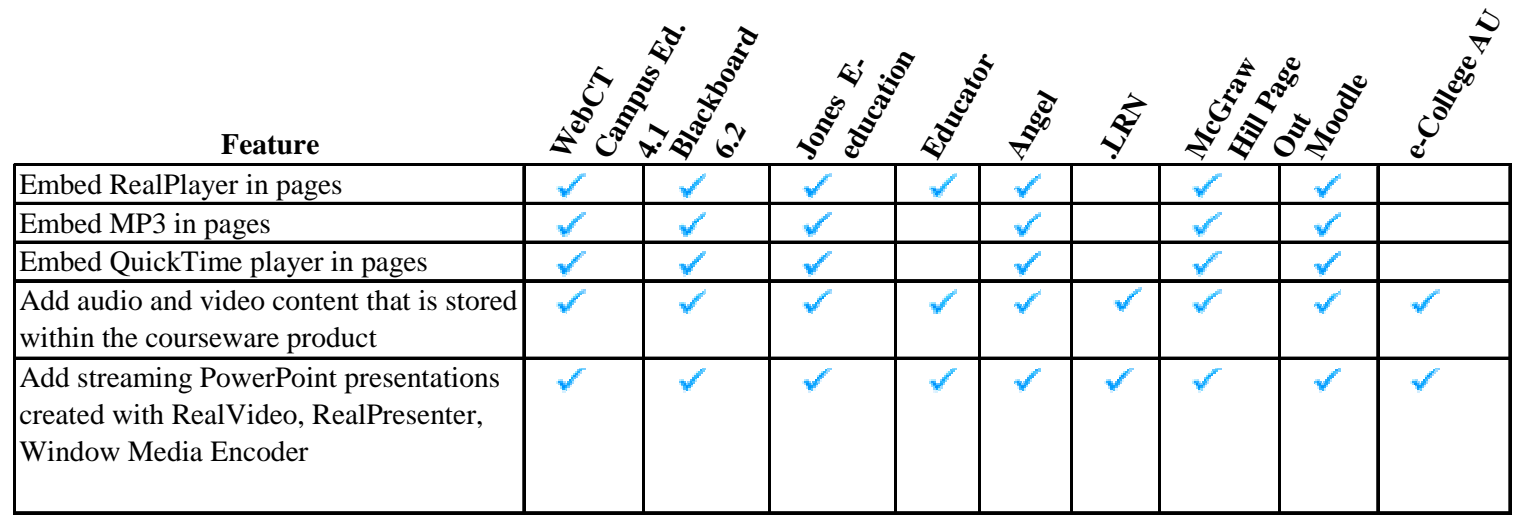

(Adapted from: Lewis, MacEntee, \& Youngs-Maher, 2002)

Figure 7: Audio/Video

\section{Monitoring Student Participation and Progress}

In a traditional course, an instructor can take attendance. However, they do not know if they students are reading or paying attention to discussions. In an online course, an instructor can closely monitor a student (Figure 8). They can tell when the student enters a course and how long they are in the course at a particular time. They can also track how many discussions that a student reads and responds to. They can also track when and how many content pages that the student views.

Instructors can grade student work through assignment submission areas and have the grades placed automatically into the grade book. After instructors have graded the assignments, students are able to view their grades and any feedback for the assignments. Not only can students view their assignment grades but all of their grades online (Figure 8). 


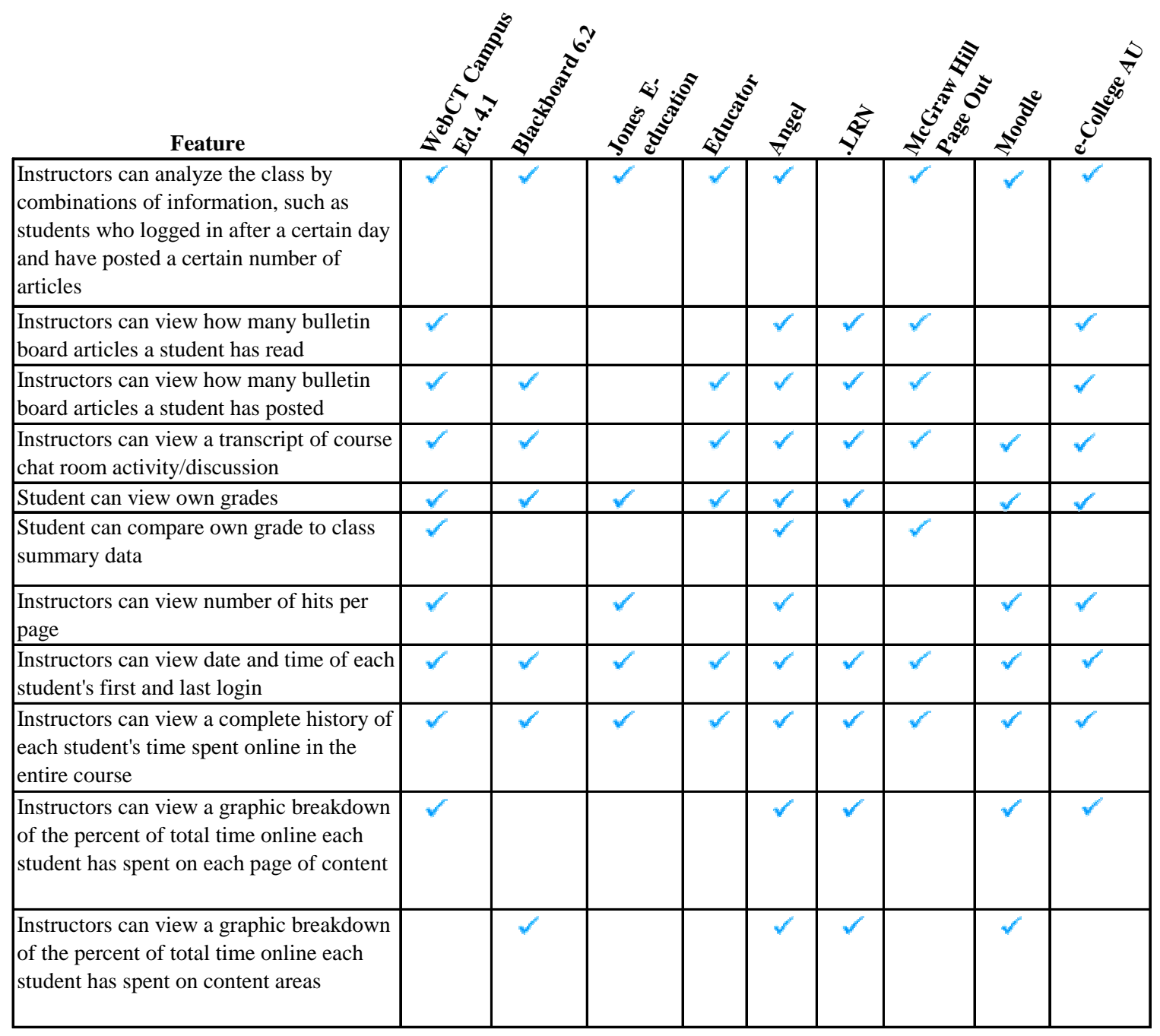

(Adapted from: Lewis, MacEntee, \& Youngs-Maher, 2002)

Figure 8: Monitoring Student Participation and Progress

\section{Navigation and Interface}

Have you ever been a new student in a class in a new school? How long did it take you to get to the class? Did you get lost getting to class? Were you able to locate all resources in the classroom? Did you know where the library was in the school? Did you feel lost and out of place?

In an online course, an instructor wants to reduce student frustration not add to it. How the course is designed and how the student will access the information is important. Can the student navigate with ease? Simple navigation keeps learners from getting lost. The ease of navigation through the course will help the learners achieve their goals. Therefore, navigation in a LMS is crucial (Figure 9). An instructor needs an LMS that will minimize frustration and maximize learning. 


\begin{tabular}{|c|c|c|c|c|c|c|c|c|c|}
\hline Feature & & & & \langle & $\underbrace{\circ}$ & y & & 5 & $e^{\circ}$ \\
\hline $\begin{array}{l}\text { Gateway page allows users to view all } \\
\text { courses in which they are enrolled }\end{array}$ & $\checkmark$ & & $\checkmark$ & $\checkmark$ & $\checkmark$ & $\checkmark$ & $\checkmark$ & $\checkmark$ & $\checkmark$ \\
\hline $\begin{array}{l}\text { Instructor can change page design } \\
\text { globally during course design }\end{array}$ & $\checkmark$ & & $\checkmark$ & $\checkmark$ & $\checkmark$ & $\checkmark$ & $\checkmark$ & $\checkmark$ & $\checkmark$ \\
\hline $\begin{array}{l}\text { Courseware product defaults to graphic } \\
\text { interface }\end{array}$ & $\checkmark$ & $\checkmark$ & $\checkmark$ & $\checkmark$ & $\checkmark$ & $\checkmark$ & $\checkmark$ & $\checkmark$ & $\checkmark$ \\
\hline \begin{tabular}{|l|} 
Courseware product automatically \\
generates header and footer on new pages
\end{tabular} & $\checkmark$ & $\checkmark$ & $\checkmark$ & & $\checkmark$ & $\checkmark$ & $\checkmark$ & $\checkmark$ & \\
\hline $\begin{array}{l}\text { Courseware product provides multiple } \\
\text { icon and button styles }\end{array}$ & $\checkmark$ & $\checkmark$ & $\checkmark$ & $\checkmark$ & $\checkmark$ & $\checkmark$ & & & $\checkmark$ \\
\hline $\begin{array}{l}\text { Instructor can substitute buttons or icons } \\
\text { of own design }\end{array}$ & $\checkmark$ & & $\checkmark$ & $\checkmark$ & $\checkmark$ & & & & \\
\hline $\begin{array}{l}\text { Instructor can specify a customized course } \\
\text { banner }\end{array}$ & $\checkmark$ & $\checkmark$ & $\checkmark$ & $\checkmark$ & $\checkmark$ & $\checkmark$ & & $\checkmark$ & $\checkmark$ \\
\hline $\begin{array}{l}\text { Instructor can select a custom background } \\
\text { color or graphic }\end{array}$ & $\checkmark$ & $\checkmark$ & $\checkmark$ & $\checkmark$ & $\checkmark$ & $\checkmark$ & $\checkmark$ & $\checkmark$ & $\checkmark$ \\
\hline \begin{tabular}{|l|} 
Courseware product can display \\
components of the interface in a language \\
other than English (in student-view only)
\end{tabular} & $\checkmark$ & $\checkmark$ & $\checkmark$ & & $\checkmark$ & $\checkmark$ & & $\checkmark$ & $\checkmark$ \\
\hline Users can view course map & $\checkmark$ & $\checkmark$ & $\checkmark$ & & $\checkmark$ & & & & \\
\hline Users can search course content & $\checkmark$ & & $\checkmark$ & & $\checkmark$ & $\checkmark$ & & $\checkmark$ & \\
\hline
\end{tabular}

(Adapted from: Lewis, MacEntee, \& Youngs-Maher, 2002)

Figure 9: Navigation and Interface

\section{Site Administration}

The LMS must provide maximum flexibility to support the ongoing needs of both experienced and novice faulty. Does the LMS provide the instructors with a full range of flexible teaching and learning tools that can meet the needs of diverse students? Can instructors customize the structure, presentation, and delivery of their classes to meet their needs? The ease-of-use for both faculty and students is paramount to the success of an online course (Figure 10). 


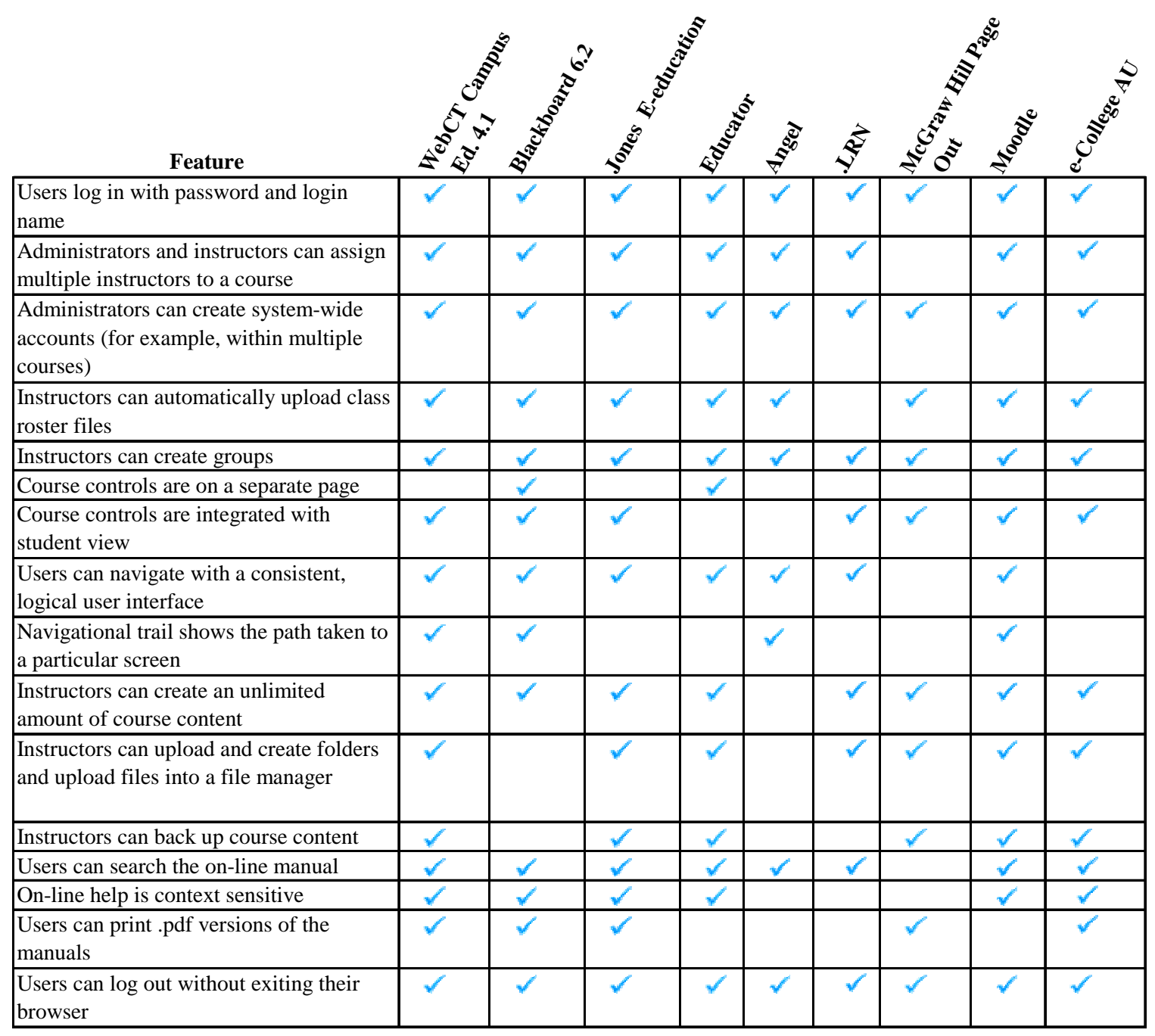

(Adapted from: Lewis, MacEntee, \& Youngs-Maher, 2002)

Figure 10: Site Administration

\section{Summary}

A learning management system must address the needs of the ultimate end user: the learner. Each LMS has key features that allow students to be actively involved in their courses. The different learning management systems extend teaching and learning and engage learners in a deeper learning experience.

The usability of the learning management system is the key to the effectiveness and efficiency of the online course. Instructors need to understand the different components of the LMS and how these components will work to make the course effective and efficient. The LMS should be able to create pedagogically sound course content and learning objects easily and efficiently. It should have all the necessary e-learning tools for assessment, communication, collaboration, and community building, as well as for the creation and management of online learning courses. 


\section{References}

ANGEL Learning, Inc. (2005). Retrieved January 27, 2005, from http://www.angellearning.com

Berns, T. (2004). Usability and user-centered design, a necessity for efficient e-learning!. International Journal of the Computer, the Internet and Management, 12(2), 20-25. Retrieved February 28, 2005, from http://www.journal.au.edu/ijcim/2004/may04/p20-25-Tomas\%20Berns-paper-usabeility.pdf

Blackboard (2005). Retrieved January 27, 2005, from http://www.blackboard.com/

eCollege (2005). Retrieved January 27, 2005, from http://www.ecollege.com

Edutools (2005). Retrieved February 21, 2005, from http://edutools.com

Jones Knowledge, Inc. (2005). Retrieved January 27, 2005, from http://www.jonesknowledge.com

Lewis, B., MacEntee, V, \& Youngs-Maher, P. (2002). Software compare and contrast: Blackboard-WebCT and Lotus Notes Dominos. 2002 Informing Science + IT Education Conference and Proceedings, Ireland. Retrieved December 18, 2005, from http://proceedings.informingscience.org/IS2002Proceedings/papers/lewis167softw.pdf

McGraw Hill Pageout (2005). Retrieved January 27, 2005, from http://pageout.net

Moodle.com (2005). Retrieved January 27, 2005, from http://moodle.org

Ucompass Product (2005). Retrieved January 27, 2005, from http://www.ucompass.com

WebCT (2005). Retrieved January 27, 2005, from http://www.webct.com/

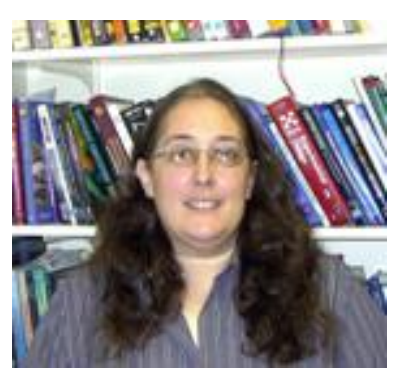

\section{Biographies}

Barbara Lewis, Ph.D. is currently a professor at Lamar University teaching Educational Technology. She has designed and taught online courses in Instructional Technology. Barbara has been creating online courses for the last six years in the university setting. Prior to working in academia, she was an instructional design consultant within the corporate environment.

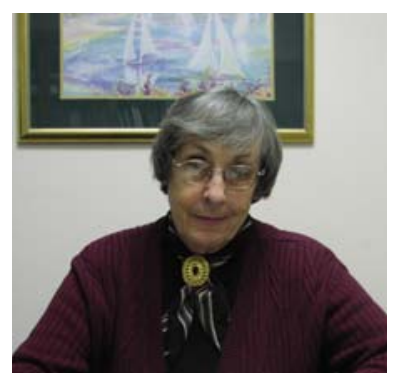

Virginia MacEntee, Ed.D. is currently a professor at the State University of New York at Oswego teaching in the School of Education, B.S. Degree Program -Childhood Education1-6. She has designed and taught online courses for the SUNY Learning Network. 


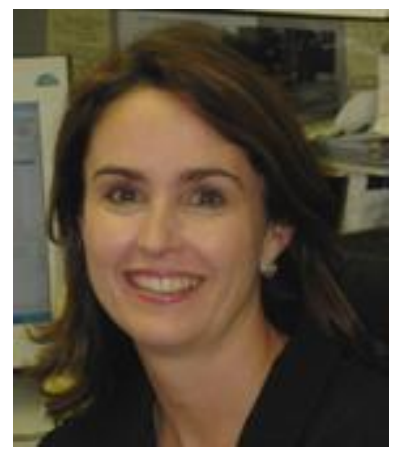

Shirley DeLa Cruz is a Program Officer for the Beaumont Foundation of America. She taught middle school for 12 years in the Port Arthur and Nederland, Texas school districts. Shirley earned a Bachelor of Science degree in Secondary Education from Lamar University with certifications in Mathematics and Spanish. She is currently pursuing a Masters Degree in Educational Technology Leadership.

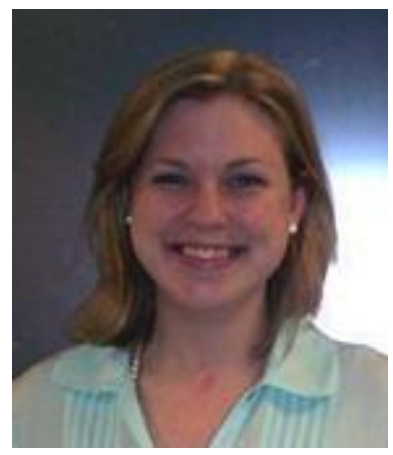

Catherine Englander is currently working on special projects at Benkenstien and Oxford L.L.P. She has served a TALH Administrative Assistance. She holds a degree in Youth and Community Services from the University of Texas at Austin and is working toward her masters in educational technology. Ms Englander is the Service in Technology advisor.

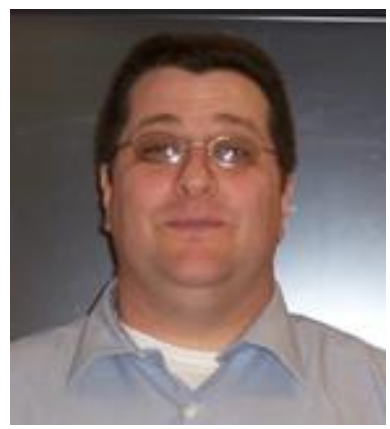

Thomas Jeffrey is a Senior Web Application Developer at the Beaumont Foundation of America. He has more than ten years of experience in planning, design and development of online applications and enterprise information portals. He has worked primarily in the advertising and telecommunications sectors, where he delivered solutions for Pepsi, Mountain Dew, DreamWorks Pictures, GTE, and Level 3 Communications.

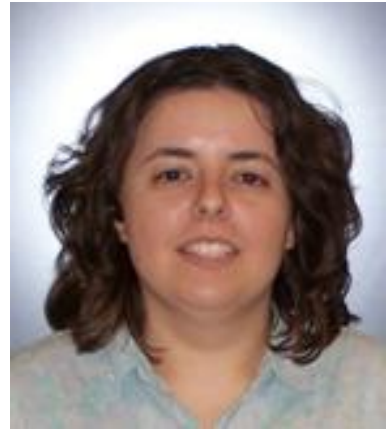

Elizabeth Takach is a graduate student working on her Masters of Education at Lamar University. She received her BA in Management Information Systems from Lamar University. 


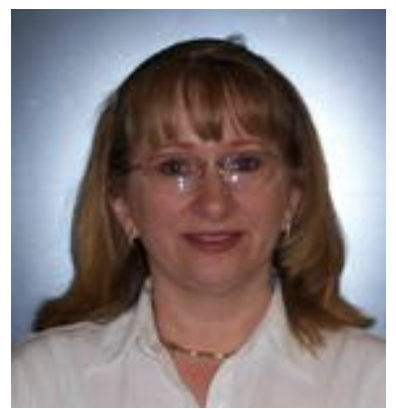

Sharon Wilson is employed as an Instructor of Business and Computer Information Systems at Lamar Institute of Technology in Beaumont, Texas. Sharon earned an AAS degree in Business and Computer Information Systems from Lamar Institute of Technology, BAAS degree from Lamar University, and is currently pursuing a Master's degree in Educational Technology Leadership.

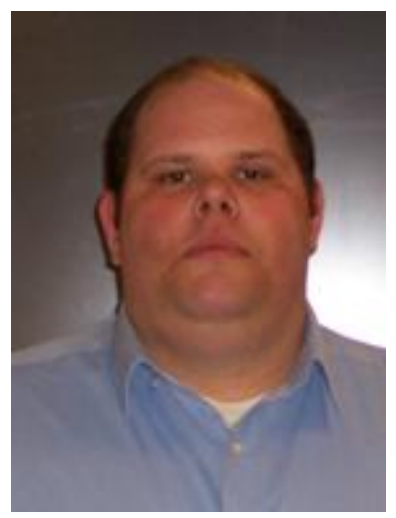

Jason Woodall is currently pursuing a Master's Degree in Educational Technology and a Post Baccalaureate Teacher Certification in Business Composite from Lamar University. Jason has a B.B.A. in Management Information Systems from Lamar University and has seven years of experience as a computer technician/network administrator working in various educational, public and private industries. 